\title{
The Effects of Internal Corporate Social Responsibility on Employees Performance Through Organizational Commitment in Hospitality Industry
}

\author{
Rina Ekawati \\ Diploma III Hospitality \\ Akademi Pariwisata Pertiwi \\ Jakarta, Indonesia \\ rina.ekawati@pertiwi.ac.id
}

\author{
Ari Djanuar Prasetyo \\ Pertiwi Research Institutions and Community Service \\ Jakarta, Indonesia \\ ari.januar.p@gmail.com
}

\begin{abstract}
This study aims to find the implementation of Internal CSR, then exploring the effects of internal corporate social responsibility (CSR) that impact on employee's performance through organizational commitment in hospitality industry. The author used the questionnaires which distributed to the employees at hospitality industry, such as the four and five star hotels in Jakarta. Researcher is use the quantitative methods by collecting the distribution of questionnaires, processing data with Tetrad IV based on comprehensive research design by path analysis. Internal CSR in this research represented by four dimensions, namely training \& education (X1), health \& safety (X2), workplace diversity (X3), and work-life balance (X4), while the organizational commitment $(Y)$ and performance $(Z)$. The results of this study suggest that managers should focus on the factor that have a significant effect on organizational commitment and find out the impact toward employees performance.Also only one variable (work life balance) which has mediating between organizational commitment and employee's performance, the variable as a moderating variable.
\end{abstract}

Keywords-internal CSR, employees performance, organizational commitment, and hospitality industry

\section{INTRODUCTION}

The concept of corporate social responsibility (CSR) is increasingly being discussed, both by academics from various disciplines of management (Hansen et al., 2011) and practitioners.

Philip Kotler in Suherman Kusniadji (2011), reveal some reasons of the need to hold the company's CSR activities. CSR can build brand positioning, boost sales, expand market share, increase employee loyalty, reduce operating costs, and improve corporate attractiveness in the eyes of investors.

According to Wibisono, the benefits of CSR for companies such as, maintain or boost its reputation and brand image of the company, deserves a social license to operate, reducing the business risk of the company, expanded access to resources, access to the market spread, reduce costs, improve relations with stakeholders, improve relations with regulators, boost morale and productivity of employees, providing opportunities for recognition, and some other benefits.

The present research to address gaps in analyzing the effect of internal CSR on organizational commitment of employees.

Definition of internal CSR activities are directly related to the physical and psychological work environment employees regarding their health and well-being, training and participation in their organization, equal opportunities and work-life balance (Turker, 2009).

Internal CSR variables selected as independent variables. Five dimensions are used as the measuring instruments the Internal CSR training and education, health and safety, work life balance, workplace diversity and human rights (Al-bdour, A.Ali, Ellisha Nasruddin., and Soh Keng Lin, 2010)

Organizational commitment variables selected as the dependent variable for the study of organizational behavior, organizational commitment of employees is one of the overlooked concept. The impact of this behavior on the effectiveness and success of the company is very large(AlSmadi,2008). Organizational commitment is also widely believed to be one of the key factors that determine the relationship between the individual and the organization (Sharma \& Bajpai, 2010).

Educational institutions is an engaged institution in services with a concentration in a draw between education and community service, which will print the next generation. Thus, the CSR movement was applied according to the needs of the community and the academic community.

Miller (2003, p 73) states that organizational commitment is a condition in which an employee identifies with the organization and its goals, and want to maintain their membership in the organization.

Based on the above, the formulation of the problem in this research is: How the influence of internal CSR on organizational commitment of employees?

This study was based on research conducted Al-bdour et al (2010), titled The Relationship Between Internal Corporate Social and Organizational Commitment Responsibiity within 
the Banking Sector in Jordan). In this study the internal dimension of CSR that will be studied is limited to only a few dimensions of the training \& education, remuneration \& recognition, workplace diversity and work - life balance. While the organizational commitment of employees that will be studied is the configuration of the three perspectives ie, normative commitment, affective commitment and continuance commitment.

In 2010 al - Bdour, Ellisha , \& Soh Keng conducted a study to examine the relationship between internal CSR and organizational commitment. Internal CSR components studied are: Work -life balance, training \& education, human rights, health \& safety, and workplace diversity. The results showed that each component of internal CSR on banks in Jordan are at a statistically significant level to encourage employee commitment. Research conducted by Keraita et al (2013) about the influence of internal CSR on employee organizational commitment also reached the same conclusion with previous studies. In this study the internal CSR is represented by four independent variables, namely: training, safety, work-life balance and workplace diversity. The findings showed that the four elements of internal CSR are positively correlated with employee commitment.

According Sinambela, et al (2012) suggested that the performance of employees is defined as the ability of an employee to do something specific expertise. Similar with Rivai \& Basri (2004) Harsuko (2011) terms of performance or the performance is the result of work that can be achieved by a person or group of people in a company in accordance with the authority and responsibilities of each in achieving corporate objectives illegally, do not break the law and not contrary to morals and ethics.

Based on the above, the formulation of the problem in this research is: How the influence of organizational commitment on performance of employees?

Khan, et al (2010) found a positive relationship between affective commitments on employee performance, also Yetta Tri Nydia (2012) found a significant effect of organizational commitment on employee performance.

The aim of this research is to validate the theoretical model and hypothesis and describe the influence of internal entanglement between CSR and organizational commitment also the effect to performance of employees.

\section{RESEARCH METHODS}

Respondents selected from managerial and non-managerial staff of three hotel with four star hotels criteria in Jakarta and were given same questionnaire with purposive sampling was used to the employee who have been work two years unil ten years at all departemen in the hotel. All of the respondents indicated their opinion about internal CSR, they feel about organizational commitment, and their performance.

From two hotels, all of them complete questionnaires and returned, each one were distributed by researcher 20 questionnaires but one hotel returned 18 questionnaires, and

the other hotel, returned 16 questionnaires, total 34 questionnaires.

Researcher collecting questionnaires for two weeks in October 2016.

Eight items were used to measure training \& education variables (TX1), five items were used to measure remuneration \& recognation variables (TX2), five items were used to measure workplace diversity variables (TX3), and five items were used to measure worklife balance variables (TX4). Out of these nineteen items were used to measure organizational commitment (TY), and twenty six items were used to measure employee's performance (TZ). Total sixty eight items were used to measure all of variables.

Research is an interval measurement scale (Likert), where the number $5=$ strongly agree, $4=$ agree, $3=$ moderately agree, $2=$ disagree, $1=$ strongly disagree.

Statistical tools such as Tetrad IV software used by researchers to process the data, which is followed by a descriptive analysis of quantitative data to test hypothesis and path analysis model.

\section{RESULT AND DISCUSSION}

TABLE I. .NORMALY TEST

\begin{tabular}{lcccccc}
\hline UJI & TX1 & TX2 & TX3 & TX4 & TY & TZ \\
Kolmogorof & & & & & & \\
Smirnov & 0.13 & 0.14 & 0.18 & 0.18 & 0.19 & 0.14 \\
Signifikansi & 0.05 & 0.05 & 0.05 & 0.05 & 0.05 & 0.05 \\
\hline
\end{tabular}

Normaly score testing:

H0: normal distribution

H1: not normal distribution

Kolmogorof Smirnov < Significant so H0 rejected.

TX1:0.13> 0.05,H0 accepted, normal distribution

TX2:0.14 > 0.05,H0 accepted, normal distribution

TX3:0.18 > 0.05,H0 accepted, normal distribution

TX4:0.18> 0.05,H0 accepted, normal distribution

TY: $0.19>0.05, \mathrm{H} 0$ accepted, normal distribution

TZ: $0.14>0.05, \mathrm{H} 0$ accepted, normal distribution

Based from using Tetrad IV software to process the data, the validity test of questionnaire items and the result showed that all items which belong to internal CSR, organizational commitment and employee's performance were valid and reliable.

Researcher build the research design and doing a model test. 


\section{A. Model Testing}

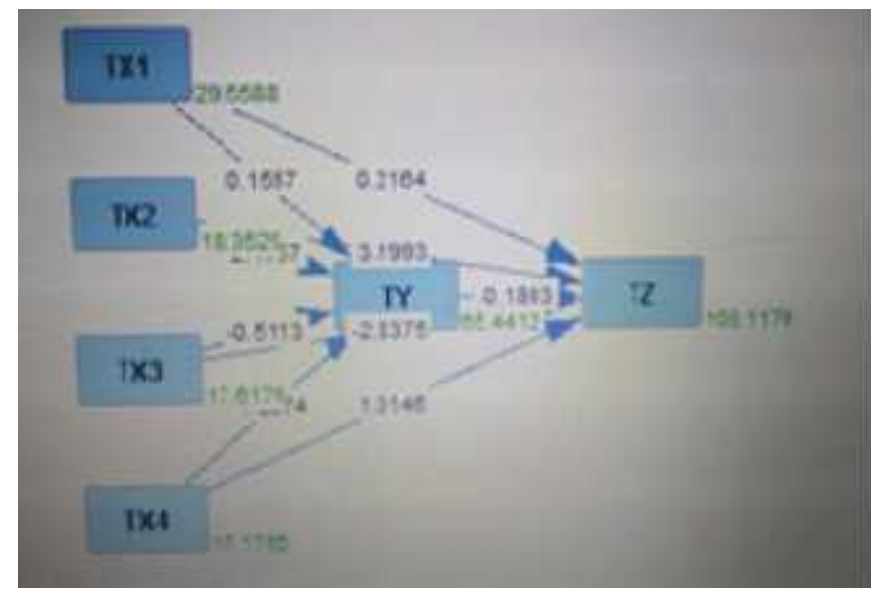

Fig. 1. Model Test

\section{B. Hypothesis Testing}

\section{$\mathrm{B} 1: \mathrm{TX} \mapsto \mathrm{TY}$}

H1: training \& education has a positive significant effect on organizational commitment

$\mathrm{H} 1:$ significant $=\mathrm{P}$ value $>$ significant $0.7071>0.05$, so H0 is acceped, H1 is rejected, means training \& education have a positive but not significant effect on organizational commitment.

$\mathrm{B} 2: \mathrm{TX} \rightarrow \mathrm{TZ}$

$\mathrm{H} 2$ : training \& education have direct effect toward an employee's performance

$\mathrm{H} 2$ : signifikan $=\mathrm{P}$ value $>$ significant

$0.6894>0.05$, so H0 is acceped, H1 is rejected, means training \& education have direct effect toward an employee's performance

$\mathrm{B} 3: \mathrm{TX} 2 \rightarrow \mathrm{TY}$

H3 : remuneration \& recognation have a positive significant effect on organizational commitment

$\mathrm{H} 3:$ signifikan $=\mathrm{P}$ value $<$ significant $0.0016<0.05$, so $\mathrm{H} 0$ is rejected, $\mathrm{H} 1$ is acceped, means remuneration \& recognation have a positive significant effect on organizational commitment

$\mathrm{B} 4: \mathrm{TX} 2 \rightarrow \mathrm{TZ}$

H4 : Remuneration \& recognation have direct effect toward an employee's performance

$\mathrm{H} 4:$ signifikan $=\mathrm{P}$ value $<$ significant $0.0061<0.05$, so $\mathrm{H} 0$ is rejected, $\mathrm{H} 1$ is acceped, means remuneration \& recognation have direct effect toward an employee's performance

$\mathrm{B} 5: \mathrm{TX} 3 \rightarrow \mathrm{TY}$

H5 : workplace diversity has a positive significant effect on organizational commitment

$\mathrm{H} 5$ : signifikan $=\mathrm{P}$ value $>$ significant $0.4687>0.05$, so H0 is acceped, $\mathrm{H} 1$ is rejected, means workplace diversity has a positive but not significant effect on organizational commitment

$\mathrm{B} 6: \mathrm{TX} 3 \rightarrow \mathrm{TZ}$
H6 : workplace diversity has direct effect toward employee's performance

$0.0040<0.05$, so $\mathrm{H} 0$ is rejected, $\mathrm{H} 1$ is acceped, means workplace diversity has direct effect toward an employee's performance

B7 : TX4 $\rightarrow$ TY

H7: work life balance has a positive significant effect on organizational commitment

$\mathrm{H} 7$ : signifikan $=\mathrm{P}$ value $<$ significant

$0.0178<0.05$, so $\mathrm{H} 0$ is rejected, $\mathrm{H} 1$ is acceped, means work life balance has a positive significant effect on organizational commitment

B8 : TX4 $\rightarrow \mathrm{TZ}$

H8: Work life balance has direct effect toward an employee's performance

$\mathrm{H} 8$ : signifikan $=\mathrm{P}$ value $>$ significant

$0.1987>0.05$, so H0 is acceped, H1 is rejected, means work life balance has not direct effect toward an employee's performance.

$\mathrm{B} 9: \mathrm{TY} \rightarrow \mathrm{TZ}$

H9 : Organizational commitment has a positive significant effect on employee's performance

$\mathrm{H} 9$ : signifikan $=\mathrm{P}$ value $>$ significant $0.4328>0.05$, so H0 is acceped, H1 is rejected, means organizational commitment has a positive but not significant effect on employee's performance

\section{Mediation testing}

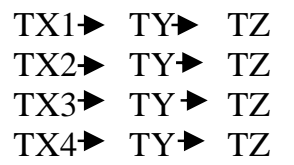

Direct effect < Indirect effect, H0 rejected, there is mediating variable

\section{TABLE II. MEDIATION TESTING}

$\begin{array}{llll}\text { Kausalitas } & \text { Direct } & \text { Indirect } & \text { Mediating } \\ \text { TX1,TY } & 0.3791 & 0.3011 & \text { not mediate } \\ \text { TX1,TZ } & 0.4032 & & \\ \text { TX2,TY } & 3.4501 & 2.7401 & \text { not mediate } \\ \text { TX2,TZ } & 2.9313 & & \\ \text { TX3,TY } & 0.733 & 0.5821 & \text { not mediate } \\ \text { TX3,TZ } & 3.0946 & & \\ \text { TX4,TY } & 2.4949 & 1.9814 & \text { mediate } \\ \text { TX4,TZ } & 1.3118 & & \\ \text { TY,TZ } & 0.7942 & & \end{array}$

Based on Tabel 3. Mediation testing, the study revealed :

$\mathrm{TX} 1 \rightarrow \mathrm{TY} \rightarrow \mathrm{Z}$ the variabel can not mediate, because direct effect $>$ indirect effect, $0.4032>0.3011$ so $\mathrm{H} 0$ accepted

TX2 $\rightarrow$ TY $\quad$ Z the variabel can not mediate, because direct effect $>$ indirect effect, $2.9313>2.7401$ so H0 accepted 
$\mathrm{TX} \rightarrow \mathrm{TY} \rightarrow \mathrm{TZ}$ the variabel can not mediate, because direct effect > indirect effect, $3.0946>0.5821$ so $\mathrm{H} 0$ accepted

$\mathrm{TX} \rightarrow \mathrm{TY} \rightarrow \mathrm{TZ}$ the variabel can mediate, because direct effect $<$ indirect effect, $1.3118>1.9814$ so $\mathrm{HO}$ rejected

The study revealed that internal CSR has a positive effect on organizational commitment but not significant effect toward an employee's performance.

Most of the executives and managerial employees giving attention to the implementation of internal CSR also doing such strategies to increase organizational commitment which impacted an employee's performance.

\section{CONCLUSIONS}

The purpose of these study was explained empirically test the effect of internal CSR on organizational commitment to find out the impacted toward employee's performance.

The results of this study suggest that managers should focus on the factor that have a significant effect on organizational commitment and find out the impact toward employees performance

Also only one variable (work life balance) which has mediating between organizational commitment and employee's performance, the variable as a moderating variable.

\section{REFERENCES}

Al-bdour, A., Elisha, N., \& Soh Keng, L. (2010). The Relationship between Internal Corporate Social Responsibility and Organizational Commitment within the Banking Sector in Jordan. International Journal of Business and Economic Sciences

Al-Smadi, M.Dan Gult. (2008). Past, Present, and Future of e-Assessment:Towards a Flexible e-Assessment System. The article on Conference ICI, Villach, Austria

Hansen, S.D., Dunford B.B., Boss Alan D., Boss R.W., Angermeier. (2011). Corporate Social Responsibility and the Benefits of Employee Trust: A CrossDisciplinary Perspective, Jurnal Bus Ethics

Keraita, Joash Mukamba, Margaret A Oloko, Charles Munene. (2013), The influence of internal corporate social responsibility on employee commitment in the banking sector: a survey of commercial banks in kisii town, Kenya, International Journal of Arts and Commerce, January 2013

Khan, B., Farooq, A., \& Hussain, Z. (2010). Human resource management: an Islamic Perspective. Asia Pacific Journal of Business Administration, 2 (1): 17-34

Miller George A, (2003). The cognitive revolution:a historical perspective, TRENDS in Cognitive Sciences Vol.7 No.3 March 2003
Riniwati, Harsuko. (2011). "Mendongkrak Motivasi dan Kinerja: Pendekatan Pemberdayaan SDM". Malang: UB

Rivai dan Basri. (2004). Manfaat Penilaian Kinerja. Retrieved from ,http://jurnal-sdm.blogspot.com/2004/04/penilaiankinerja-karyawan-definisi.html

Sharma, J.P. and Bajpai, N. (2010) Organizational commitment and its impact on job satisfaction of employees: A comparative study in public and private sector in India, International Bulletin of Business Administration, 9, 7-19

Sinambela, Lijan Poltak. 2012. Kinerja Pegawai. Yogyakarta: Graha Ilmu

Sulaiman, M., Sabian, N. A. A., \& Othman, A. K. (2014). The Understanding of Islamic Management Practices Among Muslim Managers in Malaysia. Asian Social Science, 10 (1):189-199

Tri Nydia Yetta (2012), "Pengaruh Komitmen Organisasional Terhadap Kinerja Karyawan Lapangan SPBU Coco Pertamina Mt Haryono". Thesis. Universitas Indonesia

Turker, D. (2009). Measuring Corporate Social Responsibility: A Scale Development Study. Journal of Business Ethics. 